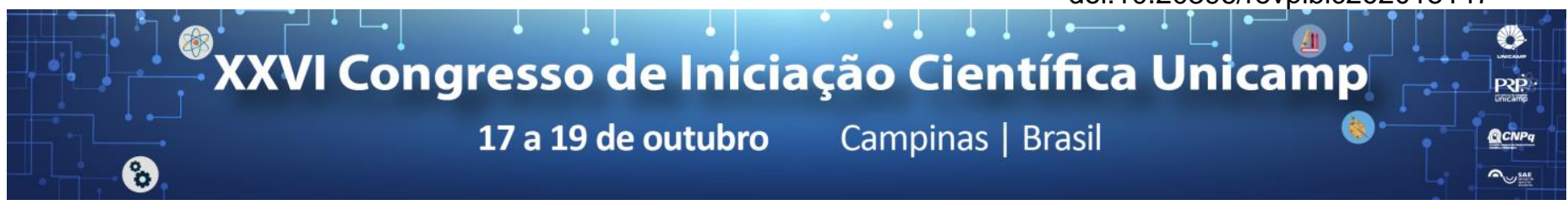

\title{
Ecos do franquismo (1948-1955) no pinochetismo (1973-1975)
}

\section{André Mateus Pupin*, José Alves de Freitas Neto.}

\section{Resumo}

O presente projeto de pesquisa tem como escopo mapear a apropriação do autoritarismo franquista pelo pinochetismo. Partimos da produção cultural da hispanidad pelos Cuadernos Hispanoamericanos para os discursos de Pinochet no funeral de Franco, onde a hispanidad estava presente.

\section{Palavras-chave:}

História da América; História Cultural; História Intelectual.

\section{Introdução}

Após a Guerra Civil espanhola, em 1939, Francisco Franco subiu ao poder na Espanha, onde ficou até 1973 como presidente, e até sua morte, em 1975, como líder do exército. Sua vitória nesse conflito interno deveu-se muito ao apoio dos exércitos fascistas de Hitler e Mussolini sendo que a Espanha quase participou da $2^{a}$ Guerra Mundial ao lado do Eixo. Por não ter entrado no conflito Franco continuou no poder, porém, com um impasse: por ser um governo que aliou-se ao nazismo e ao fascismo, encontrou-se isolado no panorama político internacional.

Com o objetivo de estabelecer vínculos diplomáticos e zonas de influência, a Espanha criou em 1948 os Cuadernos Hispanoamericanos sob a tutela do Ministério de Assuntos Exteriores. Tal revista intelectual, especialmente entre 1948 e 1955, representou a pretensão franquista de estabelecer vínculos de dominação cultural com as antigas colônias da América, girando em torno dos conceitos de catolicidad e hispanidad.

Já em 1975 Pinochet foi o único chefe de Estado a comparecer ao funeral de Franco, fazendo colocações representativas da sua admiração e inspiração com o franquismo. Tais discursos foram ampliados com a sua divulgação através de meios midiáticos chilenos ( $E I$ Mercúrio, por exemplo).

\section{Resultados e Discussão}

Por tratar-se de pesquisa iniciada em junho de 2018, ainda não há resultados. Sendo assim nos propomos a discutir, no presente congresso, algumas questões amplas do projeto:

1) Estudo de diferentes temporalidades: 1948-1955 e 1973-1975;

2) Estudos transnacionais;

3) Análise de discursos políticos.

\section{Conclusões}

O mapeamento das apropriações culturais do Chile pinochetista para com a Espanha franquista que está sendo feito a partir da análise dos Cuadernos Hispanoamericanos e dos pronunciamentos de Pinochet pretende-se, com o uso da bibliografia selecionada, compreender os caminhos ideológicos e discursivos no interior da cultura política chilena no referido recorte temporal. Conceituando, descrevendo e explicando o autoritarismo pinochetista e suas apropriações do franquismo pretende-se contribuir, dentro das limitações de uma Iniciação Científica, tanto para a compreensão do fenômeno autoritário franquista na Espanha e pinochetista no Chile, como para a História Intelectual e Política de maneira geral.

\section{Agradecimentos}

Agradeço ao meu orientador prof. Dr. José Alves de Freitas Neto, tanto pela orientação como por todo apoio.

Agradeço também às tantas Anas e tantas Lívias que tornaram esta iniciação científica possível.

\footnotetext{
1 FINCHELSTEIN, Federico. Fascismo trasatántico: ideología, violencia y sacralidad en Argentina y en Italia, 1919-1945. Buenos Aires: Fondo de Cultura Económica, 2010.

2. HINOJOSA, Isabel Jara. De Franco a Pinochet: el proyecto cultural franquista en Chile, 1936-1980. Santiago: Lom Ediciones, 2006.

3, MARTINS, Maria Antonia Dias. A Identidade Ibero-americana em revista: Cuadernos Americanos e Cuadernos Hispanoamericanos, 1942-1955. Tese apresentada à Faculdade de Filosofia, Letras e Ciências Humanas da Universidade de São Paulo para obtenção do título de Doutora em História Social. 2012.
} 